\section{PATHOGENETIC APPROACHES TO THE TREATMENT OF ROTAVIRUS INFECTION IN CHILDREN}

O.M. Naumenko

SUMMARY. The results of treatment of 134 children aged 3 months to 5 years with a diagnosis of rotavirus infection. Efficiency scheme using a combination of Saccharomyces Boulardii mixture NAN lactose-free and treatment of rotavirus infection in children by analyzing the clinical symptoms and laboratory parameters. It is established that the use of a mixture of NAN lactose-free combined with Saccharomyces Boulardii significantly reduces the length of the main clinical manifestations and RVI accelerates the elimination of the virus from the gut.

Key words: rotavirus infection, lactose-free diet, children.

Отримано 24.02.2016 р.

\title{
ЗМІНИ ЕТІОЛОГІЧНОГО СПЕКТРУ ЗБУДНИКІВ ЛЕПТОСПІРОЗУ СЕРЕД НАСЕЛЕННЯ НА ТЕРНОПІЛЛІ
}

Тернопільський державний медичний університет ім. І.Я. Горбачевського, ДУ «Тернопільський обласний лабораторний центр ДСЕС України»

Тернопільська область $є$ ендемічною по лептоспірозу. Ії природні умови (слабколужні чи лужні ґрунти, температура повітря, достатня кількість опадів) сприяють існуванню основного природного резервуара збудника - мишоподібних гризунів. На території області постійно виділяються різні сероваріанти лептоспір від гризунів і сільськогосподарських тварин. Проведений аналіз циркуляції збудників хвороби між різними джерелами (гризуни, інші тварини) і щорічної захворюваності населення свідчить про те, що нові серовари лептоспір заносяться здебільшого сільськогосподарськими тваринами, від яких через довкілля інфікується людина, іноді з інтервалом 3-5 років; спостерігається подальше розповсюдження нових для даної території сероварів збудника у всіх видів обстежених мишоподібних гризунів. Встановлено, що сільськогосподарські тварини і гризуни є конкуруючими резервуарами. Для прогнозування подальшої епідситуації з лептоспірозу серед населення та покращення його діагностики необхідний постійний моніторинг чисельності, інфрікованості та лептоспіроносійства серед мишоподібних гризунів і сільськогосподарських тварин й розширення набору діагностичних штамів лептоспір з урахуванням нових варіантів збудників у тварин.
Ключові слова: лептоспіроз, захворюваність населення, джерела інфекції, мишоподібні гризуни, сільськогосподарські тварини.

Лептоспіроз - широко розповсюджене інсекційне захворювання як серед людей, так і у тварин. Хвороба характеризується переважно тяжким перебігом, високою летальністю, надає великі соціальні та економічні збитки. За деякими оцінками, щорічно у світі реєструється серед населення 1,03 млн випадків і 58900 смертей від лептоспірозу. Найвищі показники захворюваності та летальності відзначаються у південній та південно-східній Азії, Океанії, на Карибах, у Латинській Америці, східній Афрриці [1]. В Україні хвороба реєструється практично в усіх областях, також і у Тернопільській області.

Ендемічність території з лептоспірозу визначається насамперед наявністю основного природного резервуара збудників - мишоподібних гризунів, а також природнокліматичними умовами (у тому числі кислотністю ґрунтів, кількістю опадів, температурою повітря [2, 3]), які сприяють їх збереженню і розповсюдженню. Джерелом зараження лептоспірозом для людини можуть бути також тварини - і не лише в розпал хвороби, але й довгий час після видужання. Встановлена тривалість лептоспіроносійства у 
великої рогатої худоби до 6 міс., у свиней - до 1 року, у собак - 2-3 роки; до 10 \% ВРХ і 30 \% свиней залишаються носіями пожиттєво, так само як щури й миші [4]. Однак деякі автори [5] вважають, що на більшості територій свійські та сільськогосподарські тварини не відіграють значної ролі в епідеміології іктерогеморагічного лептоспірозу, оскільки майже завжди в цих осередках виявляють щурів.

Мета дослідження - вивчити закономірності епідемічного та епізоотичного процесів лептоспірозу, проаналізувати циркуляцію його збудників між різними джерелами (гризуни, сільськогосподарські тварини) і людиною.

\section{Матеріали і методи}

Проаналізовано матеріали відділу особливо небезпечних інфекцій дУ «Тернопільський обласний лабораторний центр ДСЕСУ», обласної державної лабораторії ветеринарної медицини, клініки інфекційних хвороб ТДМУ. Лептоспіри виявляли методом темнопольної мікроскопії (ТМП) крові пацієнтів, відловлених гризунів, обстежених сільськогосподарських тварин. Серовар збудника визначали за даними серологічного обстеження в реакції мікроаглютинації з відповідними живими культурами лептоспір (РМАЛ); стандартний діагностичний набір складався 3 лептоспір 11 серогруп (13 сероварів), що включали одночасно діагностичні штами, запропоновані ВООЗ, і штами, виділені на території України, ідентифріковані відповідно до міжнародних еталонних культур: Icterohaemorrhagiae (cepoвар copenhageni, штам M-20), Javanica (poi, poi), Canicola (canicola, Каширський), Autumnalis (autumnalis, Akiyami «A»), Australis (bratislava, Еж №1), Pomona (pomona, pomona), Grippotyphosa (grippotyphosa, Moscow V), Bataviae (diatzi, HS-26), Tarassovi (tarassovi, Перепеліцин), Hebdomadis (wolffi, 3705), Pyrogenes (pyrogenes, Salinem), Ballum (castellonis, Castellon-3), Cynopteri (cynopteri, VI 3868).

Інфрікованість гризунів, за даними комплексного лабораторного обстеження (ТПМ + РМАЛ), у дійсності в 1,6-1,9 разу більша, ніж за офріційними даними, які надаються лише за результатами РМАЛ, проте позитивний результат тільки ТПМ не дозволяє визначити серовар збудника.

Вивчено захворюваність населення на лептоспіроз у Тернопільській області за 1980-2015 рр., інфікованість тварин у домашніх і колективних господарствах, а також гризунів у природних умовах.

\section{Результати досліджень та їх обговорення}

Рівень захворюваності людей на лептоспіроз у Тернопільській області коливався в широких межах 1,05-12,17 на 100 тис. населення (2-149 випадків за рік); найбільший підйом припадав на 1992-2001 рр., пік спостерігався в 1994 р., за 2014 р. - 3,26 (мал. 1), що постійно перевищувало середньодержавний показник, і протягом багатьох років був найвищим в Україні.

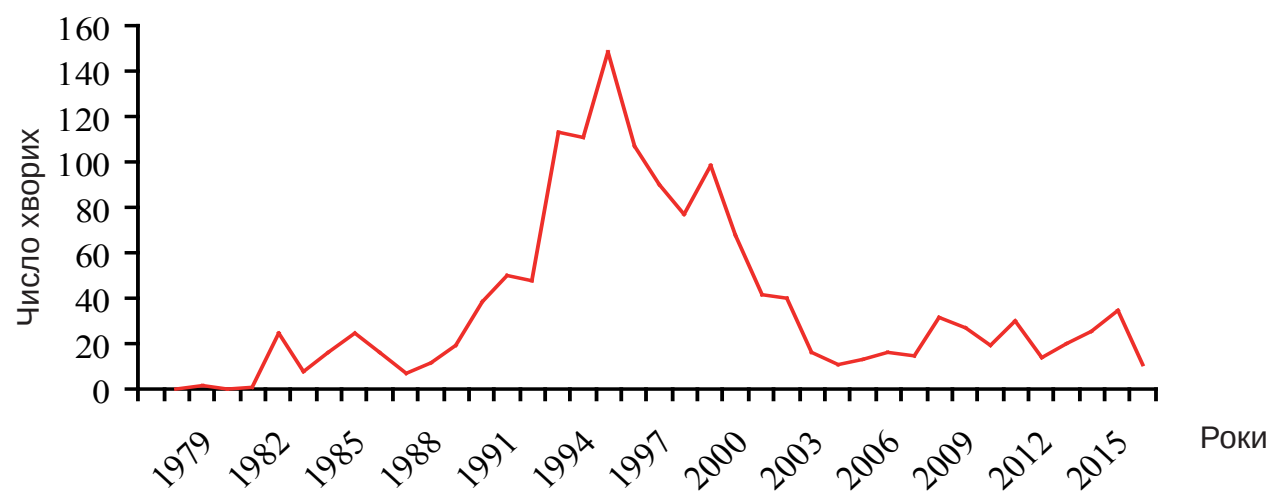

Мал. 1. Захворюваність на лептоспіроз людей у Тернопільській області (1979-2015рр.).

Аналіз етіологічної структури свідчить про значні її зміни за роки спостереження. До 1981 р. включно головну роль відігравала L. grippotyphosa (90 \% етіологічно розшифррованих випадків лептоспірозу), у наступні роки відсоток цієї лептоспіри в структурі захворювань знизився до 41,1-51,4 \% (1988-1989 рр.), згодом до 3,4 \% (1994р.), в 1999-2000 рр. не виявлено жодного випадку лептоспірозу, спричиненого цим збудником. У 90-ті роки основним етіологічним фрактором була L. icterohaemorrhagiae (в 1991 р. - 93,2 \%, у 2000 р. - 100,0 \%); зрідка захворювання були пов'язані з іншими серогрупами лептоспір. 32002 р. реєструються захворювання, спричинені L. hebdomadis
(5,9-23,4-45,4 \%), L. canicola (14,2-34,4-60,0\%), L. pomona (3,1-15,4-21,4 \%); частка L. icterohaemorrhagiae скоротилася до 37,5 \%, випадки L. grippotyphosa поодинокі й лише в окремі роки (мал. 2). В останні роки суттєво зросла частка поєднаного лептоспірозу (34,3 \% 3 усіх зареєстрованих у 2014 р.).

Зіставлення етіологічного спектру лептоспірозу у людей і основного резервуара - мишоподібних гризунів на першому етапі спостереження (1982-1993 рр.) не показує їх повного співпадіння (табл. 1). Так, у природних біотопах у різних видів полівок, польової і хатньої миші, а також економки виявляли здебільшого антитіла 


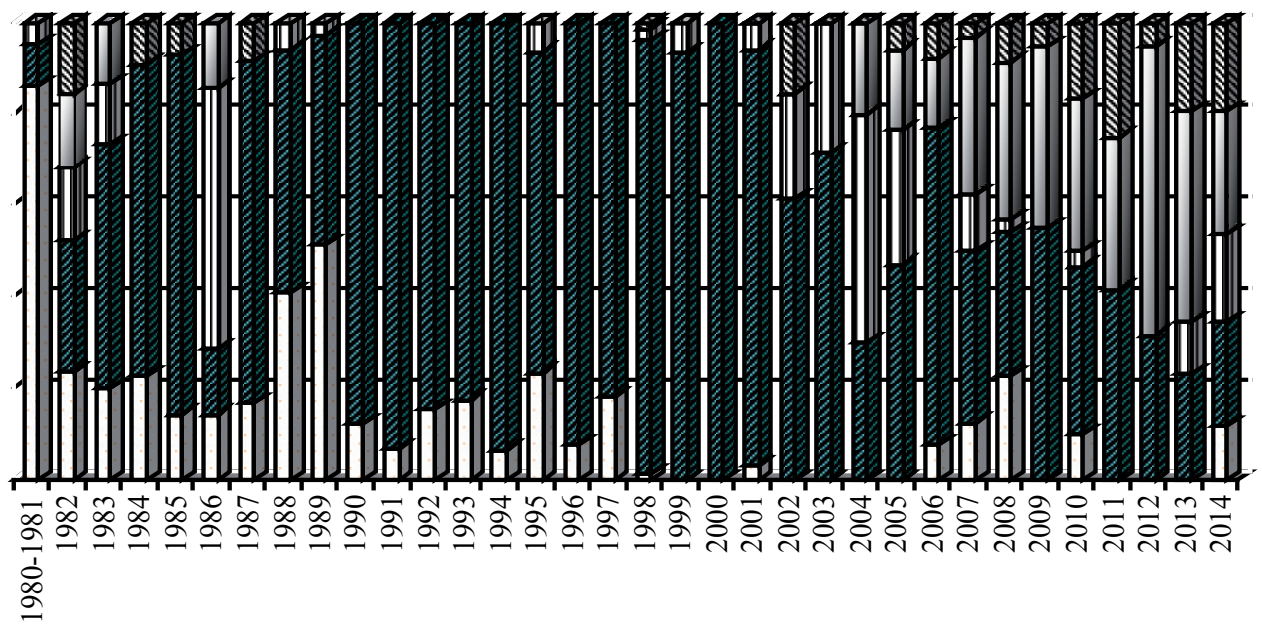
$\square$ L. grippotyphosa
L. icterohaemorrhagiae
四L. hebdomadis
L. canicola
$\mathbb{Q}$ L. pomona

Мал. 2. Етіологічна структура лептоспірозу у хворих на Тернопільщині (щорічна питома частка збудників, 1980-2015 рр., \%).

до лептоспір серогрупи Grippotyphosa; в основного мешканця домашніх осередків сірого пацюка - лише Icterohaemorrhagiae. Від жовтогорлої полівки і хатньої миші, в тому числі у домашніх осередках, знаходили також Hebdomadis. У людей за той же період реєструвались захворювання, спричинені як перерахованими збудниками, так і Canicola та Pomona (1982 р.), у подальшому Kabura (2005), Polonica (2007), яких у гризунів до того часу не виявляли (мал. 2). Також у 2010 р. зареєстровано випадок лептоспірозу в людини, спричинений L. australis - зараження, ймовірно (за даними епіданамнезу), відбулось на іншій території, джерело інфекції не було встановлено.

У подальшому від мишоподібних гризунів почали виявляти антитіла й до інших сероварів лептоспір: Canicola - у щурів (2004, 2007 рр.), Kabura (2006); у різних видів полівок і польових мишей, крім Grippotyphosa, також Icterohaemorrhagiae, Pomona, Canicola, Hebdomadis, тобто відбулось розширення спектру збудників з подальшим їх розповсюдженням у всіх видів обстежених мишоподібних гризунів. В 2015 р. від гризунів уперше виділено лептоспіру Polonica.

Таблиця 1

Видовий склад гризунів у природних біотопах і населених пунктах та інфікованість їх різними серогрупами лептоспір (1982-2014 рр.)

\begin{tabular}{|c|c|c|c|}
\hline \multirow{2}{*}{ Вид гризуна } & \multicolumn{3}{|c|}{ Виявлено антитіла до лептоспір } \\
\hline & 1982-1993 pp. & 2001-2007 pp. & 2010-2014 pp. \\
\hline Полівка звичайна & $\mathrm{Gr}$ & & Ict, Gr, Pom, Can, Hebd \\
\hline Полівка руда & $\mathrm{Gr}$ & & Ict, Gr, Pom, Can, Hebd \\
\hline Полівка жовтогорла & Gr, Hebd & & Can \\
\hline Полівка водяна & $\mathrm{Gr}$ & & - \\
\hline Землерийка & $\mathrm{Gr}$ & & - \\
\hline Миша польова & $\mathrm{Gr}$ & & Ict, Gr, Pom, Can \\
\hline Миша хатня & Gr, Hebd, Ict & Ict, Hebd, Can, Kabura & Ict, Gr, Pom, Can, Hebd, Polonica \\
\hline Миша економка & $\mathrm{Gr}$ & & - \\
\hline Пацюк сірий & Ict & Ict, Can & Ict, Gr, Hebd, \\
\hline Миша маля & - & & Ict, Can \\
\hline
\end{tabular}

Примітки: Gr - серовар Grippotyphosa, Ict - Icterohaemorrhagiae, Hebd - Hebdomadis, Can - Canicola, Pom - Pomona.

На теренах Тернопільської області постійно реєструється наявність серологічно позитивних до лептоспірозу сільськогосподарських тварин у домашніх, колективних і фрермерських господарствах (табл. 2). 
Результати серологічного обстеження сільськогосподарських тварин на лептоспіроз і серовари виявлених збудників (2001-2014 рр.)

\begin{tabular}{|l|l|l|l|}
\hline \multirow{2}{*}{ Критерій } & \multicolumn{1}{|c|}{$2001-2005$ рр. } & \multicolumn{1}{c|}{ 2006-2010 pp. } & \multicolumn{1}{c|}{ 2011-2014 pp, } \\
\cline { 2 - 4 } \% інсрікованості & \multicolumn{1}{|c|}{$108151 / 2465 *$} & \multicolumn{1}{c|}{$109618 / 1413$ * } & 1,61 \\
\hline У т.4. BPX & 2,28 & 1,29 & $22406 / 387(1,73 \%)$ \\
\hline свині & $79674 / 1294(1,62 \%)$ & $77226 / 681(0,88 \%)$ & $34502 / 342(0,99 \%)$ \\
\hline коні & $27348 / 1110(4,06 \%)$ & $29837 / 538(1,80 \%)$ & $1784 / 214(11,99 \%)$ \\
\hline L. icterohaemorrhagiae & $1129 / 61(5,40 \%)$ & $2466 / 194(7,87 \%)$ & $239(25,3 \%)$ \\
\hline L. pomona & $1186(48,1 \%)$ & $157(11,1 \%)$ & $40(4,2 \%)$ \\
\hline L. grippotyphosa & $116(4,7 \%)$ & $29(2,0 \%)$ & $76(8,1 \%)$ \\
\hline L. tarassovi & $48(1,9 \%)$ & $61(4,3 \%)$ & $3(0,3 \%)$ \\
\hline L. kabura & $35(1,4 \%)$ & $6(0,4 \%)$ & $60(6,4 \%)$ \\
\hline L. polonica & $95(3,9 \%)$ & $185(13,1 \%)$ & $62(6,6 \%)$ \\
\hline L. hebdomadis & $281(11,4 \%)$ & $173(12,2 \%)$ & - \\
\hline L. bratislava & $22(0,9 \%)$ & $12(0,8 \%)$ & $79(8,4 \%)$ \\
\hline L. canicola & - & $231(16,3 \%)$ & $23(2,4 \%)$ \\
\hline Поєднані & - & $11(0,8 \%)$ & $218(23,1 \%)$ \\
\hline
\end{tabular}

Примітка: у чисельнику - число тварин, у знаменнику - число серопозитивних особин.

Етіологічна структура лептоспірозу тварин різноманітна і включає LL. icterohaemorrhagiae, pomona, grippotyphosa, hebdomadis, polonica, canicola, kabura, tarassovi, 32007 р. реєструється L. bratislava (y 2008 р. серед свиней - 87,5 \%), дуже часто одночасно виявляються діагностично значущі титри антитіл до двох різних сероварів (71,4-78,0 \% у ВРХ, 2003-2006 рр.). Будь-якої залежності щодо провідного серовару збудників у різні роки і різних тварин встановити не вдалось.

Причинами серопозитивності тварин можуть бути вакцинальний процес, природне зараження або захворювання тварин. Однак L. kabura (L. hebdomadis),
L. bratislava у складі вакцин для тварин немає. Хоча клінічно виражених фрорм лептоспірозу, падежу, абортів не спостерігалось, антитіла визначались у досить високих титрах (до 1:400), що дає підстави говорити про носійство або субклінічну форму хвороби у тварин і вважати їх потенційними джерелами лептоспірозу для людини. Не виключається можливість інфрікування при поповненні поголів'я тварин з інших господарств та інших територій.

Зіставлено спектр збудників, визначених серологічно, за час спостереження у людей, сільськогосподарських тварин та мишоподібних гризунів (табл. 3).

Таблиця 3

Збудники лептоспірозу, визначені серологічно у тварині людей (1972-2015рр.)

\begin{tabular}{|l|l|l|}
\hline \multicolumn{1}{|c|}{ Гризуни } & \multicolumn{1}{|c|}{ Свійські і сільськогосподарські тварини } & \multicolumn{1}{c|}{ Люди } \\
\hline L. icterohaemorrhagiae (1972) & L. icterohaemorrhagiae (1972) & L. icterohaemorrhagiae (1972) \\
\hline L. grippotyphosa (1972) & L. grippotyphosa (1972) & L. grippotyphosa (1972) \\
\hline L. canicola (1982, 2004) & L. canicola (1979) & L. canicola (1982) \\
\hline L. pomona (2008) & L. pomona (1979) & L. pomona (1982) \\
\hline L. hebdomadis (1983) & L. hebdomadis (1981) & L. hebdomadis (1981) \\
\hline L. kabura (2006) & L. kabura (2002) & L. kabura (2005) \\
\hline L. polonica (2015) & L. polonica (2002) & L. polonica (2007) \\
\hline & L. tarassovi (2002) & \\
\hline & L. bratislava (2007) & L. australis (2010) \\
\hline & &
\end{tabular}


Проведений аналіз і наші попередні дослідження [6-8] дозволяють констатувати зв'язок захворювань людей 3 наявністю відповідних сероварів лептоспір саме у сільськогосподарських тварин, оскільки дані збудники від мишоподібних гризунів на території області раніше не виділялись.

Поява нових сероваріантів лептоспір, що заносяться здебільшого сільськогосподарськими тваринами і від яких через довкілля інфікується людина, у населення реєструється зазвичай через 3-5 років після виділення їх від тварин. Спостерігається подальше розповсюдження нових для даної території сероварів збудника у всіх видів обстежених мишоподібних гризунів.

Отже встановлено, що сільськогосподарські тварини і гризуни є конкуруючими резервуарами збудників лептоспірозу. Для прогнозування подальшої епідситуації 3 лептоспірозу серед населення та покращення його діагностики необхідний постійний моніторинг чисельності, інфікованості та лептоспіроносійства серед мишоподібних гризунів і сільськогосподарських тварин і розширення набору діагностичних штамів лептоспір 3 урахуванням нових варіантів збудників у тварин.

\section{Висновки}

1. Зміна етіологічної структури лептоспірозу людей на ендемічній території зумовлена появою додаткових резервуарів серед тварин із циркуляцією серед них інших сероварів збудників, яких не було в основного природного резервуара - мишоподібних гризунів.

2. За час спостереження відбулось розширення спектру збудників при захворюванні лептоспірозом населення з подальшим їх розповсюдженням у всіх видів обстежених мишоподібних гризунів.

3. Результати виявлення збудників лептоспірозу серед різних контингентів, що вивчалися, свідчать про те, що сільськогосподарські тварини і гризуни є конкуруючими резервуарами, від яких через довкілля інорікується людина.

\section{Література}

1. Global Morbidity and Mortality of Leptospirosis: A Systematic Review / [F. Costa, J.E. Hagan, J. Calcagno et al.] // PLoS Negl. Trop. Dis. - 2015. - Vol. 9, N 9:e0003898. doi: 10.1371/journal. pntd.0003898.

2. Еколого-епідеміологічні особливості лептоспірозу на ІваноФранківщині / Н.О. Виноград, О.П. Кіріяк, Л.І. Мурзова та ін. // Сучасні інсрекції. - 2004. - № 1. - С. 60-65.

3. Кравчук Ю.А. Епізоотолого-епідеміологічні особливості лептоспірозу в Тернопільській області / Ю.А. Кравчук, Н.А. Васильєва // Анали Мечниківського інституту. - 2015. - № 2. - С. 165-171.
4. Епізоотологічні та епідеміологічні аспекти лептоспірозу в Україні / [В.І. Задорожна, С.В. Протас, Н.В. Гопко та ін.]. - К., 2014. -46 c.

5. Бернасовська Є.П. Проблема лептоспірозу в Україні / Є.П. Бернасовська, В.М. Кондратенко, О.В. Мельницька // Інсрекційні хвороби. - 1996. - № 2. - С. 37-39.

6. Захворюваність людей на лептоспіроз та інфрікованість патогенними лептоспірами гризунів у Тернопільській області / Н.А. Васильєва, Т.В. Буртняк, Б.В. Блажкевич, Л.О. Грузина // Інфекційні хвороби. - 1995. - № 2. - С. 22-25.

7. Епідеміологічні особливості лептоспірозу в західному регіоні України / [Н.А. Васильєва, Ю.А. Поліщук, О.Л. Івахів та ін.] // Інфекційні хвороби. - 2008. - № 2. - С. 14-18.

8. Васильєва Н.А. Еволюція епідемічного процесу лептоспірозу (за матеріалами Тернопільської області) / Н.А. Васильєва, О.С. Луцук, О.В. Павлів // Профрілактична медицина. - 2011. № 2. - C. 69-73.

\section{DIFFERENTIATION SPECTRUM OF ETIOLOGIC PATHOGENS FOR LEPTOSPIROSIS AMONG PEOPLE IN TERNOPIL}

N.A. Vasylieva, Yu.A. Kravchuk

SUMMARY. Ternopil region is endemic on leptospirosis. It's natural conditions (slightly alkaline or alkaline soils, temperature, sufficient rainfall) contribute to the existence of major natural reservoir of the pathogen - at small rodents. In the region permanently allocated different serovarianty of leptospira by rodents and farm animals. The circulating of pathogens between different sources (rodents, animals) and annual morbidity suggests that new leptospira serovar recorded mostly farm animals from which the environment by infected people, sometimes at intervals of 3-5 years; there is the further diffusion of new territory for this pathogen serovars examined in all kinds of small rodents. Established that livestock and rodents are competing tanks. To predict the future epidemiological situation of leptospirosis in the population and to improve it's diagnosis requires constant monitoring of the population, and infection carrier of leptospiras among small rodents and farm animals and expanding set of diagnostic leptospira strains with new variants of pathogens in animals.

Key words: leptospirosis, morbidity, source of infection, rodents, farm animals.

Отримано 22.02.2016 p. 